Article

\title{
Determinants of Sustainability and Organisational Effectiveness in Non-Profit Organisations
}

\author{
Chux Gervase Iwu ${ }^{1, *}$, Lloyd Kapondoro ${ }^{2}$, Michael Twum-Darko ${ }^{2}$ and Robertson Tengeh ${ }^{1}$ \\ 1 Department of Entrepreneurship \& Business Management, Cape Peninsula University of \\ Technology, Corner of Tenant \& Keizersgracht, Zonnebloem, Cape Town 7530, South Africa; \\ E-Mail: tengehr@cput.ac.za \\ 2 Graduate Center for Management, Cape Peninsula University of Technology, \\ Corner of Tenant \& Keizersgracht, Zonnebloem, Cape Town 7530, South Africa; \\ E-Mails: kapondorolloyd@gmail.com (L.K.); darkom@cput.ac.za (M.T.-D.) \\ * Author to whom correspondence should be addressed; E-Mail: iwuc@cput.ac.za; \\ Tel.: +27-21-460-9038; Fax: +27-86-778-0394.
}

Academic Editor: Giuseppe Ioppolo

Received: 22 May 2015 / Accepted: 13 July 2015 / Published: 17 July 2015

\begin{abstract}
This case study investigates the criteria for organizational effectiveness in non-profit organizations (NPOs) with the aim to determine how the elements of sustainability fit within the criteria. To achieve this, the study utilized the research questions: "what criteria do NPOs use to evaluate their effectiveness?" and "how is sustainability embedded in NPO effectiveness?" The research design was interpretivist, adopting focus group interviews to obtain data. Specifically, two focus group interviews were held with the top management of an NPO which revealed that both financial and non-financial criteria were equally essential for NPO effectiveness. This finding is consistent with the literature, although it contradicts the initial assumption of the study that NPO effectiveness was based more on non-financial criteria than financial criteria. The study also found that the effectiveness of an NPO should be viewed in two ways: firstly, "the full achievement of its mandate" and, secondly, "the ability to run business projects to cover cost." It also emerged that both the ability to cover costs and the achievement of a mandate should be done in a sustainable manner (a sustainable manner is seen as one that is harmonious with the natural and the socio-political environment). The results of this paper present a practical case for the management of NPOs by reiterating that the full achievement of the NPO mandate and the successful running of social projects to generate funds for sustainability are key elements of effectiveness. Given the essential role that NPOs play in developing countries, this study has
\end{abstract}


provided the foundation for more widespread enquiry into the sustainability and effectiveness of NPOs.

Keywords: organisational effectiveness; non-profit organisations; NPO sustainability; organisational performance; financial and non-financial criteria

\section{Introduction}

This study achieves its intention by examining both theoretical and empirical links between the concepts of effectiveness and that of sustainability in NPO management. It, therefore, commences with an analysis of the meaning of both concepts and trends in the development of their scholarship. While the greater part of this introduction focuses on the criteria for organizational effectiveness, the literature review that follows provides a theoretical analysis of effectiveness and sustainability with the aim to assess the probable existence of elements of sustainability within the criteria for NPO effectiveness. The literature perspective is then empirically analysed at the end of the paper. Lecy, Schmitz and Swedlund [1] argue that even though the study of organisational effectiveness has attracted scholarly attention from across the social sciences for a number of decades, there is no consensus on the measures for effectiveness in NPOs. Herman and Renz [2] had noted earlier that there was little empirical work on the study of the dimensions of non-profit organisational effectiveness. As far back as 1975 Reimann [3] also observed that there was a "controversy" that partly revolved around the criteria that could be used to assess organisational effectiveness. Essentially, Lecy et al. [1] insist that (1) unidimensional measures of effectiveness are not useful; (2) scholarship on NGO and NPO effectiveness is dominated by conceptual and theoretical works, while empirical studies remain rare; and (3) consensus on how to operationalize effectiveness remains elusive. While organisational effectiveness in profit-making institutions is, arguably, mainly determined through financial measures [4], NPOs present a different case, whereby the concept of effectiveness has little orientation to financial criteria [5,6]. In addition, NPOs exist for a broad spectrum of motives, unlike business organisations whose motives are profit based. This paper argues that NPOs use more non-financial criteria to assess organisational effectiveness than financial criteria. This makes the study of NPO effectiveness quite problematic to simply generalize. Therefore, the main research question was: "what criteria do NPOs use to evaluate their effectiveness?" The case study approach was used to determine the criteria for NPO effectiveness. Given the strong role of contingency factors in the functions of NPOs, Simons [7] reiterated that the primary purpose of case study research is to explore the "particularity, the uniqueness of the single case."

The next section articulates pertinent literature on organisational effectiveness. This is followed by an explanation of the methodology that was adopted for the study. Thereafter, we discuss the findings in relation to the research question. We also provide some practical implications of the study, conclusions, and recommendations. 


\section{Literature Review}

\subsection{Effectiveness}

Warnich, Carrell, Elbert and Hatfield [8] believe that effectiveness is a construct that is measured in terms of "doing the right things" in the resource market, the production process, and the final product market. Robbins and Judge [9] also argue that effectiveness is the achievement of goals. McShane and Von Glinow [10] support Robbins and Judge's [9] view that, before answering a question on effectiveness, clarification is required. The implication of this claim is that the definition of effectiveness is based on certain criteria. Reporting for the Fortune magazine and the Hay Group, Stark and Royal [11] state that the criteria for ranking companies into the "most rated global companies" list included the ability to attract and retain talented people, quality management, innovativeness, quality products or services, long-term investment value, financial soundness, social responsibility, wise use of corporate assets, and effectiveness in conducting business globally. For McShane and Von Glinow, [10] organisations are effective presently if they have a good fit with their external environment; when their internal subsystems are configured for a high-performance workplace; when they are learning organisations; and when they satisfy the needs of local stakeholders. In explaining these criteria, McShane and Von Glinow [10] claim that having a good fit with the external environment is essential since the organisation operates as an open system that obtains the input resources that it needs from the environment. Once fit has been achieved, the effective organisation is one that manages to coordinate its internal processes and achieve efficiency. McShane and Von Glinow also take the perspective of Kaplan and Norton [12] that the effective organisation should achieve organisational learning, use high-performance practices, and satisfy its key stakeholders.

\subsection{Effectiveness and Sustainability}

A common notion from Euclidean Geometry [13] is that "things that coincide with one another are equal to one another." We link this to sustainability and effectiveness by arguing that sustainability is a phenomenon, which is embedded in or which coincides with effectiveness. Therefore, effectiveness and sustainability should be equally important in non-profit-making organisations (NPOs). Gomis, Parra, Hoffman and Mcnulty [5] present a historical overview of the term "sustainability" and note that early civilisations and traditional societies have always accepted, axiomatically, that nature is an important element of their survival. While acknowledging that the etymological roots of the concept of sustainability is in ecology, our study takes the much wider modern conception of sustainability, which implies survival and endurance through a symbiotic relationship with the environment, society, and economy [5,14]. It is a reasonable argument that the concept of sustainability arose because the probability of goal pursuance, which dominates non-core activities is high in goal driven organisations. The concept of effectiveness and sustainability, therefore, appear related. Generally, effectiveness is a goal-attainment phenomenon. Consequently, this study holds that sustainability should be embedded in goal attainment. This study focused on NPOs and sought to determine if the criteria for NPO effectiveness that NPOs use include elements of sustainability. 


\subsection{Organisational Effectiveness}

The concept of organisational effectiveness has varying descriptions, often dating as far back as 300 years. In fact, quite recently, Upadhaya, Munir and Bount [6] reiterated the dichotomy of views among scholars on the measurement and determination of organisational effectiveness. The first view posits that organisational effectiveness is determined in financial terms, while the second view advocates for both financial and non-financial measures. Reference to the use of non-financial measures is also found in Kaplan and Norton's [12] balanced scorecard, in which three categories (customer, learning and growth, and internal business process) are identified. While Upadhaya et al. [6] acknowledge these criteria they suggest that non-financial measures include customer satisfaction, employee motivation, quality, productivity, and market share. Tracing the emergence of organisational effectiveness as a field of practice, Lecy et al. [1] point towards organisational sociology, industrial psychology, and other administrative sciences with a scholarly base in business schools and further splitting into three different schools with distinct approaches to effectiveness; namely goal attainment, resource-control (a system resource perspective), and social constructivism/reputational perspectives. The goal attainment school of thought is quite etymological and links directly to the definitions of effectiveness that have been alluded to in the previous section, while the reputational approach is particularly popular with Forbes magazine's most rated companies. In criticism of the goal attainment view of organisational effectiveness, Lecy et al. [1] believe that measures of survival and organisational growth (the system-resource approach) and reputational measures have gained popularity because of (1) the constant debate among scholars that organisational effectiveness is often difficult to track; and (2) because organisations that compete for resources do not necessarily share the same goals. One concludes that this has perhaps led to the divergent views of NPO effectiveness that are found in the literature. However, one of the strongest criticisms of the goal attainment approach was emphasised by Herman and Renz [2] who posit that goal attainment assumes that the goals are known, are stable, are not abstract, and can be measured, while data that are relevant to the attainment of the goals can be collected. These assumptions may not be met in NPOs.

\subsection{Financial and Non-Financial Components of Organisational Effectiveness}

As can be seen in Figure 1 below, the literature splits criteria to determine NPO effectiveness into non-financial criteria and financial criteria. The elements of each criterion are shown. Trends in the literature, however, show that the dichotomy depicted in Figure 1 is only basic and serves to provide the first principles of NPO effectiveness. Young, Jung and Aranson [15] argue that the assessment of NPO effectiveness is based on "standards of organisational sustainability and growth as by any objective measure of mission achievement." This assertion draws sustainability into the complex web of NPO operations. Arguments presented by Moeller and Valentinov [16] further support the trade-offs between mission achievement in NPOs and financial sustenance. Moeller and Valentinov [16] use an open system approach to show that the commercialisation of NPOs is essential in order for them to sustain their operations, which can be split into (1) mission related operations and (2) donations acquisition (understood to encompass all philanthropic contributions and volunteering). The above arguments can be understood to mean that NPO effectiveness has greater meaning if both the financial and the non-financial criteria, which are shown in Figure 1 are interpreted within the context of sustainability. 


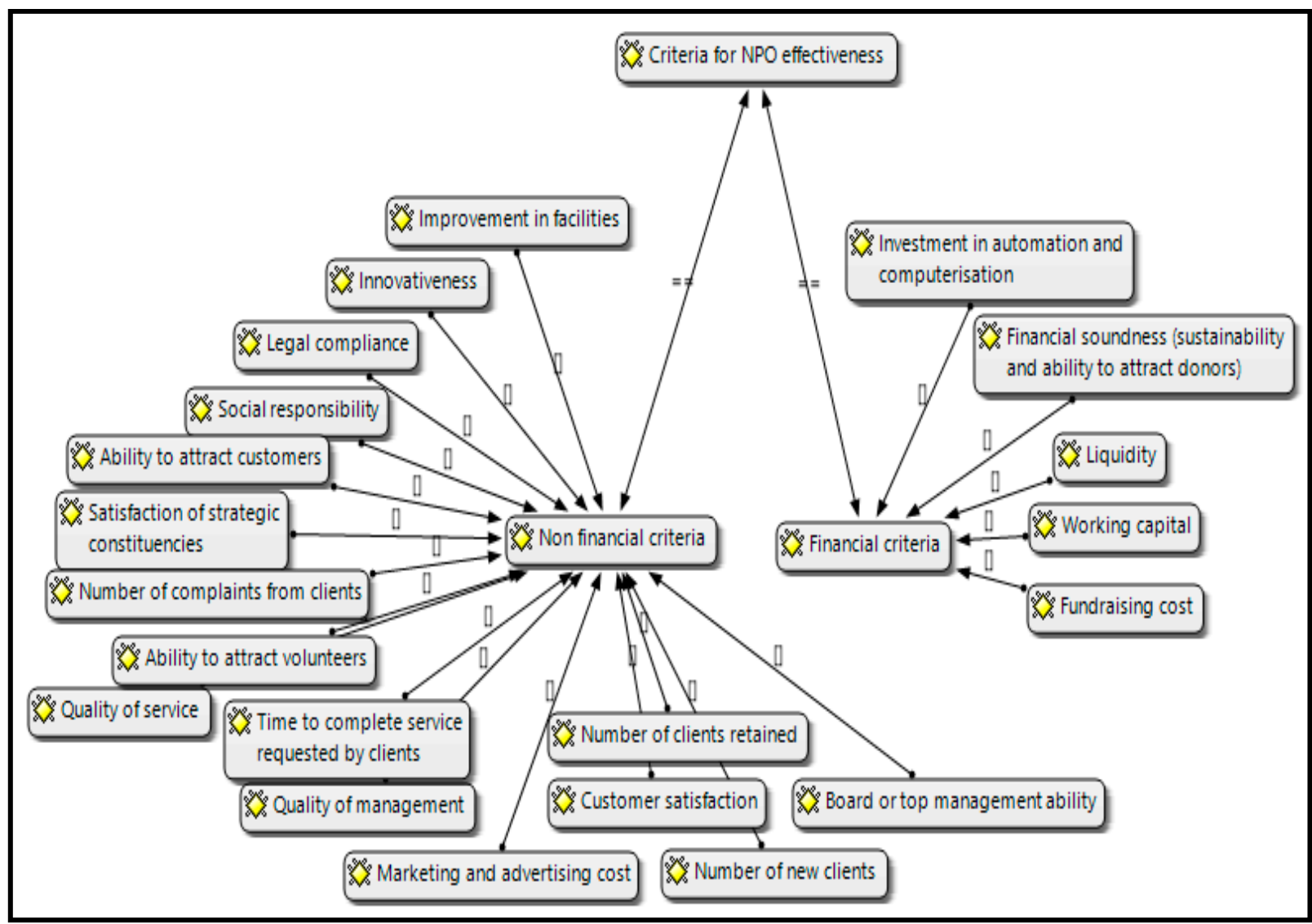

Figure 1. Literature perspective of NPO effectiveness. Source: Authors' own configuration.

\subsection{Organisational Effectiveness for Non-Profit Institutions}

The study of NPO effectiveness originally emerged as a subfield of organisational effectiveness [1] and has broadened to become a field on its own. According to Brown [17], organisational effectiveness for non-profit organisations is an elusive concept. Brooks [18] contemplates this argument further by claiming that average return on investment measures are inadequate for non-profit organisations and, therefore, NPOs should instead seek to measure marginal returns on investments in non-program areas such as administration and fund raising. Marginal returns on investment in the non-profit sector would imply ratios such as overhead to total costs, cash-on-hand to total revenues, non-fundraising expenses to total expenses, and donations to fundraising expenditures [17]. This study argues that NPOs should also check their liquidity, working capital, financial soundness, and investment in recent technology to enhance their sustainability. In support of fundraising success as criteria for NPO effectiveness, Callen [19] postulates that fund raising expenditures are equivalent to advertising expenditures in the corporate sector. Despite administration and fund raising, Callen, Klein and Tinkelman [20] found that there is a correlation between governance and efficiency in NPOs, thereby confirming that NPO governance issues are criteria for the determination of effectiveness. Major donors assess the effectiveness of NPOs based on the composition of their Board [17]. Another criterion in the determination of NPO effectiveness is its success to acquire and retain volunteers [21]. When considering the mission of NPOs and the acquisition or availability of volunteers and donations, the demand and supply sides of NPOs take focus. According to Valentinov [22], the question that implicates the demand side of an NPO is: "Why do people need this organisation?", while the question for the supply side is: "Why does somebody agree 
to contribute resources to found and operate it?" Moeller and Valentinov [16] reveal that the demand side of an NPO is determined by its mission, and the success of this mission depends on the supply side and the availability of donations. We expand this argument by showing that "mission displacement" occurs as part of the relationship with donors. Our study, therefore, interprets these arguments within the context of sustainability and effectiveness. The study seeks to assess, empirically, how the concepts of sustainability are embedded within the criteria for NPO effectiveness by using focus groups.

\section{Research Design and Methodology}

An interpretivist view of reality anchored the methodology in this study. According to Wahyuni [23], interpretivists believe that reality is constructed by social actors and peoples' perceptions of it, which is better appreciated through interaction and dialogue with a study's sample. This view was assumed appropriate for the study owing to literature arguments that NPOs vary in several criteria, including intent; thus making contingency factors critical in the assessment of effectiveness and, therefore, interaction with members of the organisation to obtain their perceptions, feelings and beliefs on the objects of this study, was critical. Hence, data were collected through interviews.

According to the Western Cape Government [24], NPOs include non-governmental organisations (NGOs), community-based organisations (CBOs), faith-based organisations (FBOs), organisations that are registered as Section 21 Companies under the Company Act 61 of 1973, trusts that are registered with the Master of the Supreme Court under the Trust Property Control Act 57 of 1988, and any other voluntary association that is not for profit. Statistics South Africa [25], however, notes that a mutually exclusive definition of NPOs is difficult to discern, but, generally, NPOs are organisations that are not-for-profit and non-profit distributing, are institutionally separate from government, are self-governing and non-compulsory. The study was limited to an NPO, which was selected from the list of NPOs that was supplied by the Western Cape Government Department of Social Development. There were 8750 NPOs on the list, of which 984 are based in Cape Town. The study was conducted in Cape Town hence the researchers' sampling frame consisted of the 984 NPOs. The selection of an NPO as a case study was based on the ideas of Seawright and Gerring [26] who suggest that there are six (6) methods of case selection; one of them, which was used in this study, is the use of an "extreme case." The extreme case is defined as that which is unusual and depicts the concept of interest more strongly. The extreme case for this study was taken to be an NPO that has endured on its mission and objectives over a long time. The researchers believe that this could be sufficient evidence for effectiveness. The years of first registration of the 984 NPOs in Cape Town were analysed from the list and the ten oldest NPOs were selected for further consideration. Of this, one was selected for meeting the criteria for the final selection.

Selection of the appropriate NPO to collect data from was carried out in phases. Firstly, the selection of NPO X (for non-disclosure of the identity of the case, the NPO will be referred to as NPO X) as the appropriate case study was done after visits were made to the ten NPO's that were selected. The purpose of the visits was to get historical accounts of these NPOs by interviewing the management; focus was on the year of formation and the major successes and failures that the NPOs had experienced since inception. While NPOs vary in their life spans, depending on the aims for which they were formed, the researchers sought an organisation with a high concern for effectiveness owing to the enduring nature of its mission and objectives. From the literature review it was gathered that the general idea enshrined in 
the concept of effectiveness was goal attainment and other appurtenances. The researchers assumed the perspective that NPOs are formed to achieve long term objectives and, therefore, those that have been sustainable have been effective. This perspective was also discussed during the preliminary interviews. At the end of these preliminary interviews two organisations remained and, finally, NPO X was chosen for analysis. NPO X has had an enduring objective, which spans decades of existence and has had significant expansion over the years. NPO X was a major player in the fight against apartheid and has recorded significant achievements to date. NPO X has, therefore, endured constraints, which are associated with various political, social, economic, and technological developments [4] in South Africa. Furthermore, its Board comprises influential and prominent personalities in South Africa. The researchers then concluded that NPO X can be a typical case of effectiveness among NPOs from which data can be collected to answer the research question.

\section{Data Collection}

Interviews with Management

The research question was: What criteria do NPOs use to evaluate their effectiveness? The researchers used criteria from the literature to develop an interview schedule, which aimed to approve or disapprove criteria for the determination of effectiveness from the literature. The financial and non-financial criteria that are depicted in Figure 1 were used to structure the interviews. The interviews also sought to add any other relevant criteria that were not obtained from the literature.

The interviews were held in the form of two (2) lunchtime focus group discussions. A snowball focus group was created by first providing the Director of the NPO with the interview schedule and requesting that he identifies colleagues with extensive experience of NPO management, as well as knowledge of the concept of effectiveness from both a scholarship and practice perspective. Thus, the sampling was purposive in nature. In the end four managers became available for the focus group. Lambert and Loiselle [27] note that the goal of a focus group is to use interaction data, which results from discussion among participants (questioning one another or commenting on one another's experiences) to increase the depth of the inquiry. In focus groups the researcher gains important insights into the phenomenon, while individual respondents share their experiences [28]. The aim of the focus group discussions was for participants to explore and indicate their level of agreement that a given criterion on the interview schedule suggests that the NPO is doing the right thing. Mansell, Bennett, Northway, Mead, and Moseley [29] argue that differences in management levels among members of a focus group lead to hierarchical differences, which not only intimidate but also make some members uncomfortable to provide information. To prevent such a situation from occurring, Mansell et al. [29] suggest that less senior members can become moderators and assistant moderators of the focus group discussion. This technique was used with the consent of the Director who committed to ensuring that all the members freely participated at the same level. A code of conduct and discussion procedure was drafted and agreed to by the participants to ensure free exchange of ideas. Two focus group discussions were then held during lunchtime with refreshments that were provided by the NPO. At the first focus group interview, half of the interview questions on the interview schedule were discussed, while the second sitting completed the schedule. 


\section{Findings and Discussion}

Data were captured and summarised in an analysis sheet shown below. In the analysis sheet the following coding was used: $\mathrm{SA}=$ Strongly agree, $\mathrm{A}=$ Agree, $\mathrm{NS}=$ Not sure, $\mathrm{D}=$ Disagree, and $\mathrm{SD}=$ Strongly disagree.

The data in Table 1 support the literature since both financial and non-financial criteria are essential for NPO effectiveness. Members of the focus group believed that customer satisfaction is a very broad element in NPO effectiveness, because it covers mission attainment and forms the social environment in which reputation and sustainability can be attained. Sustainability is also seen to intertwine with effectiveness when considering the responses of group members using the criterion- "ability to attract volunteers." The interviewees claimed that volunteers and donors have become scarce and NPOs are increasingly realizing a need to be self-reliant and sustainable. At the same time it determines effectiveness because it can be a sign that the NPO is achieving its mandate and attracting the interest of donors and volunteers. Criteria such as the ability to attract and retain talented employees and the ability to retain quality management were seen as confirmation that the NPO is viable and achieving its mandate in a manner that is internally attractive. Innovativeness and quality of service were also emphasised as critical to effectiveness and sustainability. The members of the focus group believed that NPOs should adapt and innovate in line with environmental changes. They offered that an effective NPO has creativity and innovativeness that facilitate the attainment of its mission in volatile and changing natural, economic, and socio-political conditions. Figure 1 also illustrates that the increase in demand for an NPO's services seen by the expansion, or at least retention, of its client base indicates effectiveness. Furthermore, the numbers of complaints from clients and the time that it takes to complete services, which are requested by clients, also indicate effectiveness. Internally, the NPO is expected to improve its facilities and to invest in its internal technology to facilitate mission attainment. Lastly, legal compliance is critical for the sustainability of the NPO and to maintain an operating license, while the cost that the NPO incurs in marketing itself also communicates its effectiveness.

Table 1. Focus group interview responses analysis sheet.

\begin{tabular}{|c|c|c|c|c|c|c|}
\hline Criteria & $\mathbf{S A}$ & $\mathbf{A}$ & NS & D & SD & Comment \\
\hline Customer satisfaction & $\mathrm{x}$ & & & & & $\begin{array}{l}\text { The entire group strongly agreed that this is a } \\
\text { criterion to determine NPO effectiveness. The } \\
\text { moderator summed up and stated that "we see the } \\
\text { people that we serve as clients and our funders are } \\
\text { happy when the clients are satisfied." }\end{array}$ \\
\hline $\begin{array}{c}\text { Ability to attract } \\
\text { volunteers }\end{array}$ & & $\mathrm{x}$ & & & & $\begin{array}{l}\text { The group members had no further comment when } \\
\text { one member claimed that "ability to attract } \\
\text { volunteers cannot be a very strong determinant of } \\
\text { NPO effectiveness because donors have become } \\
\text { scarce and we have to sustain ourselves." }\end{array}$ \\
\hline
\end{tabular}


Table 1. Cont.

\begin{tabular}{|c|c|c|c|c|c|}
\hline Criteria & SA & $\mathbf{A}$ & NS & SD & Comment \\
\hline $\begin{array}{c}\text { Board/top } \\
\text { management ability }\end{array}$ & $\mathrm{x}$ & & & & $\begin{array}{l}\text { There was strong agreement among group members } \\
\text { that the board/top management's ability was a } \\
\text { determinant of NPO effectiveness. The assistant } \\
\text { moderator summed up the views by stating that "the } \\
\text { Board should be composed of authorities from } \\
\text { several fields so that they can see new ventures for } \\
\text { sustainability." }\end{array}$ \\
\hline $\begin{array}{l}\text { Ability to attract and } \\
\text { retain talented people }\end{array}$ & $\mathrm{x}$ & & & & $\begin{array}{l}\text { All group members strongly agreed without } \\
\text { comment. }\end{array}$ \\
\hline $\begin{array}{c}\text { Quality of } \\
\text { management }\end{array}$ & $\mathrm{x}$ & & & & $\begin{array}{l}\text { All group members strongly agreed without } \\
\text { comment. }\end{array}$ \\
\hline Innovativeness & $\mathrm{x}$ & & & & $\begin{array}{l}\text { All group members were unanimous that NPOs } \\
\text { should be innovative, and should create a business } \\
\text { model to meet costs on one side, and deliver their } \\
\text { mandate on the other. }\end{array}$ \\
\hline Quality of service & $\mathrm{x}$ & & & & All group members agreed without comment. \\
\hline $\begin{array}{l}\text { Financial soundness } \\
\text { (sustainability and } \\
\text { ability to attract } \\
\text { donors) }\end{array}$ & $\mathrm{x}$ & & & & $\begin{array}{l}\text { The group members argued that NPOs must meet } \\
\text { their mandate and at the same time have a business } \\
\text { model to generate income to cover all costs. The } \\
\text { moderator reiterated that "NPOs should use } 100 \% \text { of } \\
\text { both donor funds and money generated from projects } \\
\text { to meet their mandate, as well as costs." }\end{array}$ \\
\hline Social responsibility & & $\mathrm{x}$ & & & $\begin{array}{l}\text { Group members agreed that social responsibility is } \\
\text { not a very strong criterion for NPO effectiveness. }\end{array}$ \\
\hline $\begin{array}{c}\text { Strategic } \\
\text { constituencies } \\
\text { satisfaction } \\
\end{array}$ & $\mathrm{x}$ & & & & $\begin{array}{l}\text { All group members agreed that the satisfaction of } \\
\text { strategic constituencies was a very strong criterion } \\
\text { that determines NPO effectiveness. }\end{array}$ \\
\hline $\begin{array}{l}\text { Number of complaints } \\
\text { from clients }\end{array}$ & $\mathrm{x}$ & & & & Group members strongly agreed without comment. \\
\hline $\begin{array}{l}\text { Time to complete } \\
\text { service requested by } \\
\text { clients }\end{array}$ & & $\mathrm{x}$ & & & Group members agreed without comment. \\
\hline $\begin{array}{l}\text { Improvement in } \\
\text { facilities }\end{array}$ & & $\mathrm{x}$ & & & Group members agreed without comment. \\
\hline $\begin{array}{l}\text { Investment in } \\
\text { automation and } \\
\text { computerisation }\end{array}$ & & $\mathrm{x}$ & & & Group members agreed without comment. \\
\hline Number of new clients & & $\mathrm{x}$ & & & Group members agreed without comment. \\
\hline $\begin{array}{l}\text { Number of clients } \\
\text { retained }\end{array}$ & & & $\mathrm{x}$ & & Group members indicated that they were not sure. \\
\hline Fundraising cost & & $\mathrm{x}$ & & & Group members agreed without comment. \\
\hline $\begin{array}{l}\text { Marketing and } \\
\text { advertising cost }\end{array}$ & $\mathrm{x}$ & & & & Group members agreed without comment. \\
\hline
\end{tabular}


Table 1. Cont.

\begin{tabular}{|c|c|c|c|c|c|c|}
\hline Criteria & SA & $\mathbf{A}$ & NS & D & SD & Comment \\
\hline Working capital & $\mathrm{x}$ & & & & & $\begin{array}{l}\text { Group members strongly agreed that the business } \\
\text { side should have good working capital ratios. }\end{array}$ \\
\hline Liquidity & $\mathrm{x}$ & & & & & $\begin{array}{l}\text { Group members strongly agreed that the business } \\
\text { side should be liquid. }\end{array}$ \\
\hline Legal compliance & $\mathrm{x}$ & & & & & $\begin{array}{l}\text { Group members strongly agreed without comment } \\
\text { that "the activities of NPOs are strongly monitored } \\
\text { by government and legal compliance is a very } \\
\text { strong criterion" }\end{array}$ \\
\hline
\end{tabular}

\subsection{Financial and Non-Financial Criteria Used by NPOs to Enhance Effectiveness}

Data that was collected in this study indicate that in order to obtain effectiveness, NPOs should adopt a two-sided approach to their operations. Firstly, the "NPO side", which focuses on delivering the mandate of the NPO and, secondly, "the business side", which involves NPO projects (either within or outside of their mandate, but intended to raise funds for operational expenses). Although the interviewees summarised NPO effectiveness in this way, it was mentioned that donor funding has dwindled and unless NPOs demonstrate that they can meet their mission, funding is likely to be lost. The challenge of achieving the NPO mission, therefore, means a need for sustainability in NPO management. The interviewees saw sustainability in terms of achieving self-reliance through selling related social activities with the aim of raising financial resources in order to cover their costs. The concept was also seen as creating reputation and visibility in the community through charitable work and community relationships. This finding supports Abraham [23] who strongly advocates for financial sustainability and accountability among NPOs. It is noted in this study that the effectiveness of an NPO means using $100 \%$ of donor funds to meet the mandate of the NPO and to cover costs, which are associated with meeting the mandate through separate projects. It is also noted that the business side of the NPO allows sustainability by providing finance to cover both the direct and non-direct costs that are associated with meeting the mandate. This idea of sustainability is consistent with Moeller and Valentinov's [16] work on the commercialisation of NPOs in which they posit that NPOs have to engage in some commercial activities in order for them to sustainably achieve their missions. Group members revealed that both financial and non-financial criteria were essential to ensure effectiveness. Whereas the financial criteria are important to determine if the financial status for both "the business/sustainability side" and "the NPO mandate side" are healthy, the non-financial criteria provided equally essential criteria to determine effectiveness. The criteria suggested in the literature were generally strongly confirmed in the interviews. The group members mentioned that periodical reviews of the NPO's mandate, budget management, operational management and people efficiency management were essential to enhance effectiveness. Some notable studies [4,30] support the findings described in this section. The results of the study suggest a need to improve the literature representation by including "sustainability" and "full achievement of mandate". Based on the findings of this study, we present a modified configuration of criteria (see Figure 2 below) for NPO effectiveness. The modified model includes the ideas of NPO sustainability and full achievement of the NPO mandate, which were found to be essential for NPO effectiveness. 


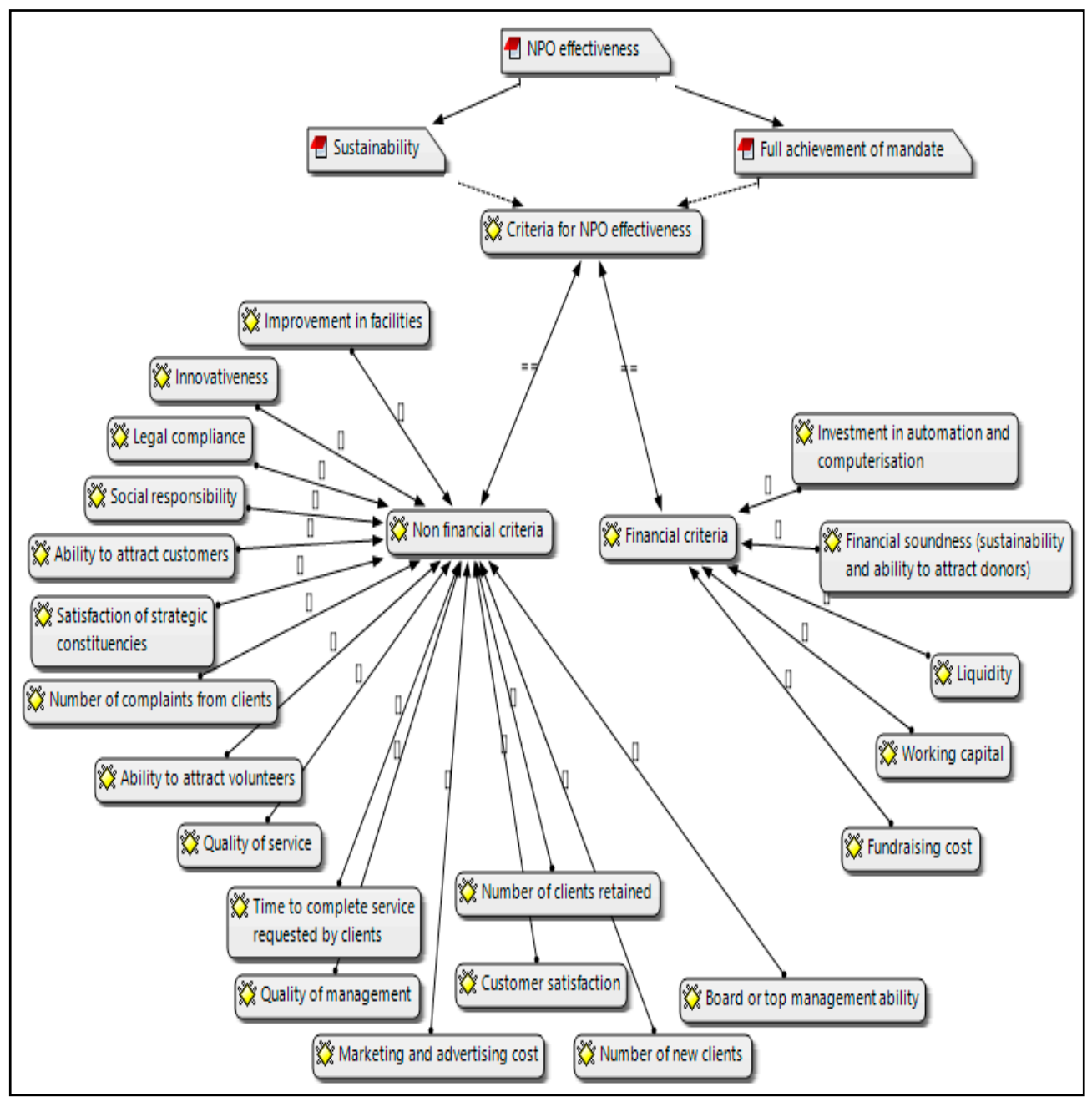

Figure 2. Criteria for NPO effectiveness Source: Authors' own configuration.

\subsection{Contingent Factors that Determine the Criteria for NPO Effectiveness}

This study has found that the importance of a criterion as a determinant of NPO effectiveness is dependent on political, economic, social, technological, environmental, and legal factors (PESTEL factors). For instance, where NPOs are in a highly volatile political environment, legal compliance and the ability to meet the requirements of key political stakeholders are critical. Equally, in a souring economic environment financial criteria are crucial. While there is much literature on the role of PESTEL factors, scholarly work on their influence on NPO effectiveness appears to be minimal. Deducing from the arguments of respondents, sustainable practices are fundamentally a way in which the threats and opportunities, which are offered by PESTEL forces can be managed. Therefore, sustainability has an anchoring role on NPO mission attainment.

\subsection{The Measurement of NPO Effectiveness}

It was also found in this study that measurement of financial criteria through basic financial accounting and analysis methods is applicable. In contrast, the measurement of non-financial criteria involves a range of methods which depend on the criteria. These methods include the use of suggestion boxes, evaluation of client satisfaction, telephone enquiries, compliments received, complaints brought forward, 
and so on. The group members indicated that every NPO should design its own methods for collecting feedback from clients and evaluating their satisfaction.

\section{Practical Implications of the Study}

The results of this study have implications for NPO effectiveness. The key implication is that a model for the management of NPOs should involve strategies for sustainability and a commitment to the attainment of the mandate of the NPO. Donors and funders are interested in the use of all of their funds on the objectives of the NPO. One way of achieving this is to have money-generating projects that aim to simply cover the costs of meeting the objectives. In this way the mandate of the NPO is achieved, while funders are satisfied, and the NPO has financial resources to be sustainable. Collaboration among NPOs and creating NPO networks can also be taken as a way of showing commitment to fulfilling NPO mandates and also provides a way to generate sustainability projects.

\section{Conclusions and Recommendation}

Both financial and non-financial criteria which assess NPO effectiveness should be used. NPOs should also ensure effective use of financial resources and should also realise that non-financial imperatives are essential for them to achieve their mandate. While this study has suggested that both the monetary and non-monetary criteria are important in assessing NPO effectiveness, we also believe that a future study may want to examine the tensions and trade-offs between these criteria. For instance, how can these tensions and trade-offs be defined, measured, and managed? This study has taken a case study approach for the determination of NPO effectiveness. The use of other methods for future research in this area may help to provide more clarity into NPO effectiveness. It is also recommended that large scale studies should be undertaken to determine NPO effectiveness, since NPOs play a great role in providing social aid to a significant portion of the population in underdeveloped and developing countries.

\section{Author Contributions}

Chux Gervase Iwu conceptualised the framework for the study and was assisted by Lloyd Kapondoro who reviewed the literature and conducted the interviews. Michael Twum-Darko and Robertson Tengeh assisted in fine-tuning the literature and results.

\section{Conflicts of Interest}

We declare that there was no conflict of interest.

\section{References}

1. Lecy, J.D.; Schmitz, H.P.; Swedlund, H. Non-Governmental and Not-for-Profit Organizational Effectiveness: A modern synthesis. Voluntas 2012, 23, 434-457.

2. Herman, R.D.; Renz, D.O. Theses on nonprofit organizational effectiveness. Nonprofit Volunt. Sect. Q. 1999, 28, 107-126.

3. Reimann, B.C. Organizational effectiveness and management's public values: A canonical analysis. Acad. Manag. J. 1975, 18, 224-241. 
4. Herman, R.D.; Renz, D.O. Advancing nonprofit organizational effectiveness research and theory. Nine theses. Nonprofit Manag. Leadersh. 2008, 18, 399-415.

5. Gomis, A.J.B.; Parra, M.G.; Hoffman, W.M.; Mcnulty, R.E. Rethinking the concept of sustainability. Bus. Soc. Rev. 2011, 116, 171-191.

6. Upadhaya, B.; Munir, R.; Bount, Y. Association between performance measurement systems and organisational effectiveness. Int. J. Oper. Prod. Manag. 2014, 34, 853-875.

7. Simons, H. Case Study Research in Practice; Sage Publications: London, UK, 2009.

8. Warnich, S.; Carrell, M.R.; Elbert, N.F.; Hatfield, R.D. Human Resource Management in South Africa, 5th ed.; Cengage Learning: Hampshire, UK, 2015.

9. Robbins, P.; Judge, T.A. Organisational Behaviour; Pearson: Upper Saddle River, NJ, USA, 2007.

10. McShane, S.L.; von Glinow, M.A. Organisational Behaviour, 5th ed.; McGraw-Hill Irwin: Boston, MA, USA, 2010.

11. Stark, M.; Royal, M. How the World's Most Admired Companies Use Corporate Culture as a Source of Competitive Advantage. HayGroup. 2013. Available online: http://www.hreonline.com/ pdfs/HREMostAdmiredforHRWebinarPresentation.pdf (accessed on 31 March 2015).

12. Kaplan, R.S.; Norton, D.P. The balanced scorecard-Measures that drive performance. Harv. Bus. Rev. 1992, 70, 71-79.

13. Zudini, V. The Euclidean model of measurement in Fechner's psychophysics. J. Hist. Behav. Sci. 2011, 47, 70-87.

14. Adams, W.M. The future of sustainability: Re-thinking environment and development in the twenty-first century. In Proceedings of the Report of the IUCN Renowned Thinkers Meeting, Gland, Switzerland, 29-31 January 2006.

15. Young, D.R.; Jung, T.; Aranson, R. Mission-market tensions and nonprofit pricing. Am. Rev. Publ. Adm. 2010, 40, 153-169.

16. Moeller, L.; Valentinov, V. The commercialization of the nonprofit sector: A general systems theory perspective. Syst. Pract. Action Res. 2012, 25, 365-370.

17. Brown, W.A. Exploring the association between board and organizational performance in nonprofit organizations. Nonprofit Manag. Leadersh. 2005, 15, 317-339.

18. Brooks, A.C. Efficient Nonprofits? Policy Stud. J. 2006, 34, 303-312.

19. Callen, J.L. Money donations, volunteering and organizational efficiency. J. Prod. Anal. 1994, 5, 215-228.

20. Callen, J.L.; Klein, A.; Tinkelman, D. Board composition, committees, and organizational efficiency: The case of nonprofits. Nonprofit Volunt. Sect. Q. 2003, 32, 493-520.

21. Plessis, L.D.; Petzer, D.J. The attitudes of donors towards non-profit organisations (NPOs) in Gauteng, South Africa: A generational perspective. Afr. J. Bus. Manag. 2011, 5, 12144-12154.

22. Valentinov, V.L. Toward an economic interpretation of the nondistribution constraint. Int. J. Not-for-Profit Law 2006, 9, 60-71.

23. Wahyuni, D. The research design maze: Understanding paradigms, cases, methods and methodologies. J. Appl. Manag. Account. Res. 2012, 10, 69-80.

24. Western Cape Government. Non-profit organisations: Registration and funding. Available online: https://www.westerncape.gov.za/service/non-profit-organisations-registration-and-funding (accessed on 1 April 2015). 
25. National Accounts. Statistics of the non-profit sector for South Africa, 2011. Available online: http://beta2.statssa.gov.za/publications/D04072/D040722011.pdf (accessed on 19 February 2015).

26. Seawright, J.; Gerring, J. Case selection techniques in case study research a menu of qualitative and quantitative options. Polit. Res. Q. 2008, 61, 294-308.

27. Lambert, S.; Loiselle, C. Combining individual interviews and focus groups to enhance data richness. J. Adv. Nurs. 2008, 62, 228-237.

28. Onwuegbuzie, A.J.; Dickson, W.B.; Leech, N.L.; Zoran, A.G. A Qualitative Framework for Collecting and Analyzing Data in Focus Group Research. Int. J. Qual. Methods 2009, 8, 1-21.

29. Mansell, I.; Bennett, G.; Northway, R.; Mead, D.; Moseley, L. The learning curve: The advantages and disadvantages in the use of focus groups as a method of data collection. Nurs. Res. 2004, 11, 79-88.

30. Weerawardena, J.; McDonald, R.E.; Mort, G.S. Sustainability of nonprofit organizations: An empirical investigation. J. World Bus. 2010, 45, 346-356.

(C) 2015 by the authors; licensee MDPI, Basel, Switzerland. This article is an open access article distributed under the terms and conditions of the Creative Commons Attribution license (http://creativecommons.org/licenses/by/4.0/). 